\title{
COMMENT AND COMICS ARTWORK BY MOHD YAMAN AHMAD MUS IN ANAK SABAH NEWSPAPER ON 1957
}

\author{
$\triangle$ Mohd Sawari Rahim \\ Fakulti Kemanusiaan, Seni dan Warisan, Universiti Malaysia Sabah \\ Jalan UMS, 88400 Kota Kinabalu, Sabah MALAYSIA \\ EE-mail: wareyzseni@gmail.com \\ Ismail Ibrahim \\ Fakulti Psikologi dan Pendidikan, Universiti Malaysia Sabah \\ Jalan UMS, 88400 Kota Kinabalu, Sabah MALAYSIA \\ E-mail: ismailbinibrahim@yahoo.com \\ Suraya Hani Zakaria \\ Jabatan Pengajian Sains Sosial, Institut Pendidikan Guru Kampus Gaya, \\ 88805 Kota Kinabalu, Sabah MALAYSIA \\ E-mail: surayahani78@gmail.com
}

Received: December 4, 2015. Revised: December 13, 2015. Accepted: December 20, 2015

\begin{abstract}
The aims for producing comics in newspaper is to convey a message instead of just an entertainment for the newspaper readers. It also can be a documentation materials for historical records and civilization history through the situation at that time. These visual images are used by Mohd Yaman Ahmad Mus to display the true story about the behavior, attitudes and moral values that apply in everyday life through his creativity and self-expression. This aims to teach and create awareness among public besides of building a harmony and well-being of the community. The display image was analyzed using a theoretical approach of iconography by Erwin Panofsky (1955). This theory was classified into three levels, which is pre-iconographic, iconography and iconological (iconology interpretation) to explain and demystify the nature and meaning of painting in a holistic manner. The study showed that the content of messages and lessons in painting shows road safety issues which are still happen since the pre-independence era in Sabah until now.
\end{abstract}

Keywords: analysis; comics; road safety issues; iconography; message; lessons

How to Cite: Rahim, M., Ibrahim, I., \& Zakaria, S. (2015). Comment and Comics Artwork by Mohd Yaman Ahmad Mus in Anak Sabah Newspaper on 1957. Harmonia: Journal of Arts Research and Education, 15(2), 88-100 doi:http://dx.doi. org/10.15294/harmonia.v15i2.4606

\section{INTRODUCTION}

The purpose of comic's illustration in printed media such as newspapers and magazines is to communicate through images with the reader by describing the scene, story, criticism, messages and lessons. Presentation of information and messages in the comic focuses on explaining the appearance of expression lines and form an image. Line plays an important role in explaining the image character that becomes 
an important element and the main focus for the painter (Ahmad Suhaimi, 2007). Types of the resulting lines such as thick, thin, circular, vertical, cascade, and others give a lot of uses and various interpretations of the meaning and expressions of artists who attempt to leave a trace of feelings, motions and mind to the viewers. The flexible line will start publishing other elements of arts such as fine art, fabric and design that will give full explanation for the image creation. The images conjured are augmented by the language appearance. Image language might seem more honest and display the effect of the evidence in the form of the writing itself. This means that art is the language of communication that is essential for channel feelings (Mahamood, 1999).

The process of drawing assessments in a newspaper is almost equal with other assessment results in the context of visual art form and meaning. The focus is based on the formalistic characters which include the lines, appearance, color, space, form, weaving, composition, movement, balance and others. The ability to analyze or characterize these formalistic characters will approach the researchers to the iconography questions or the meaning of a work. According to Mahamood (1995), both 'form' and 'content' or often called a 'rule' and 'meaning' need each other. This research will relate the context of historical, social, literary, political, aesthetic, beliefs and others. Thus, the ability of formalistic features can pave the understanding at the iconography level or meaning in the work of arts. Some of the appreciation theory and methods can be implemented in the image of the art work.

In this article the theory of iconography by Panofsky (1892-1968) was used as a scientific approach to understand, interpret and analyze works of art. Panofsky (1955) outlined a theory of iconography to get the meaning of detailed information about the issue in a work, explain, and consider the configuration on a work to understand the hidden meaning by all level.

Panofsky classified three levels of meaning that need to be identified which is basic (primary), secondary and internal (intrinsic) as shown in Figure 1. On a basic level, which also known as pre-iconographic level, the image is seen directly as a natural image and does not require any knowledge about the meaning and be able to be named only. The secondary stage or known as iconography (iconographic) which is conventional will view the images in more detail and in-depth investigation and include more concrete themes, concepts and stories. In the third stage which known as interpretation of iconology (iconological), he must be able to recognize the inner meaning of the entire work including the symbolic aspects of that field. Results at this stage will give a clear and comprehensive conclusion. Indirectly, this finding led to the message and lessons gained from the painting. Messages and knowledge gained will be classified into four criteria, which are criticism and satire, advice and guidance, moral values and motivation.

\section{FOCUSED ISSUE OF THE COMIC}

The first comic artwork (Figure 1) by Mohd Yaman Ahmad Mus that use a nickname MY 56 was published in Anak Sabah newspaper when he was 16 years old. At that time he was studying in Form 4 at All Saint's School, Jesselton, North Borneo (now is Kota Kinabalu, Sabah). The work won the grand prize in a painting contest in conjunction with road safety campaign held in 1957. He received a cash prize of 10 ringgit presented by the Police Commissioner at that time. The work was published in the 'Drawing Competition', which is a monthly column that publishes selected works by drawing competition and open to all residents of the Anak Sabah newspaper readers. 
ALWAYS TAKE CARE WHEN USING THE ROAD

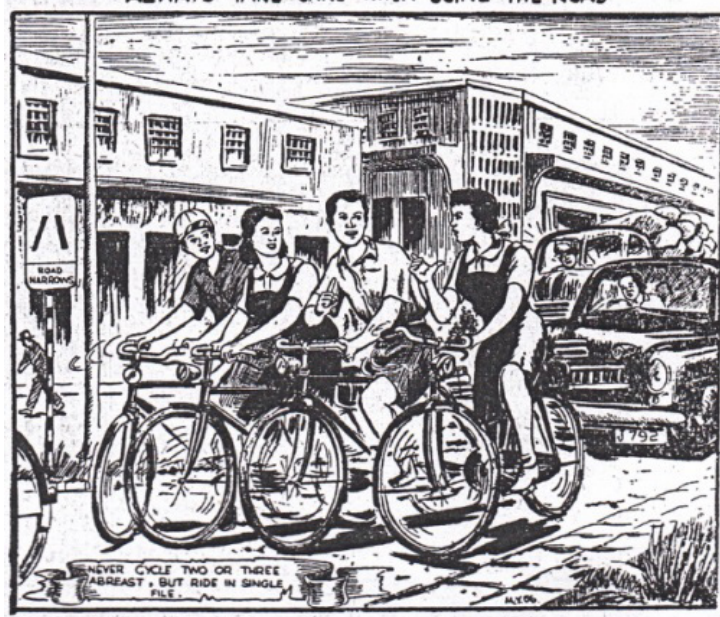

Figure 1. The Artwork of Mohd Yaman Ahmad Mus

(Source: Anak Sabah, January 1957)

\section{Textual Issue in Comic}

"Always be careful when using the road"

"Never cycle two or three abreast, but ride in single file".

"Road narrow"

\section{Analysis of Pre-Iconography Level}

This artwork shows the four main figures which are two men and two women that were seen riding a bike on a narrow road. One of them is not in a school uniform, while another three partners wear their own school uniform. The male and female characters in front of the painting looks like they are talking about something as shown by the hand and finger gestures. They talked in a warmth and happy atmosphere by the expression on the face displayed. Without realizing their behavior is being watched by two figures in two separate vehicle and heading towards the same path. A truck laden with a heavy load and the driver looks like talking something loudly (by the use of cascade lines on the face figurer) and also a slow-moving car with a calm look driver. Besides that, a pedestrian was crossing the road at the back of the drawing room next to buildings and business premises painted with the utmost care. There are signs for the "Road Narrow" and walkways as paintings background so that it can complement the description of the situation. This painting represents a realistic approach aimed at giving an overview of the actual situation on the roads treated subjects. Table 1 shows the details of the Pre-Iconography issue.

Almost all subjects in this artwork were given a touch line that shows painter's skills to form an image. Different types of lines are use as shown in Figure 1 actually play an important role in reviving the character and background of the artwork. These figures formed by simple

Table 1. Pre-Iconography Description

\begin{tabular}{|c|c|}
\hline Description & Explaination \\
\hline $\begin{array}{l}\text { Subject/ } \\
\text { Images }\end{array}$ & $\begin{array}{l}\square \text { Road safety themed issues by caption; ALWAYS TAKE CARE } \\
\text { WHEN USING THE ROAD dan NEVER CYCLE TWO OR THREE ABREAST, BUT } \\
\text { RIDE IN SINGLE FILE" } \\
\square \text { Four students, two men and two women were riding bikes in the street } \\
\square \text { A lorry and a car and a pedestrian } \\
\square \text { Signboard } \\
\square \text { Use the grounds of road and building in a city }\end{array}$ \\
\hline Shape & $\begin{array}{l}\text { Processing Elements of Art ; } \\
\square \quad \text { Smooth lines, simple, bold, repetitive, spout } \\
\square \quad \text { Connect the nature of things } \\
\square \quad \text { Appearance of various poses a tone to clarify the character and nature of objects } \\
\square \quad \text { The shape is the resulting line art, fabric and appearance } \\
\square \quad \text { Space plays a role in creating the front, middle and rear }\end{array}$ \\
\hline & $\begin{array}{l}\text { Processing Principles of Art ; } \\
\square \quad \text { The balances on the main subject in the middle, side turn on background as a real } \\
\text { characterization } \\
\square \quad \text { Confirmation of the character } \\
\square \quad \text { The rhythm of movement to the movement of the character and bicycle tires }\end{array}$ \\
\hline
\end{tabular}


and thick lines with the utmost care so that the action and character can produce maximum effect. Men and women figurer can be formed with good highlight that desired expression on the face painter. Likewise, the use of the lines on the driver's face looks calm and aggressive. For the creation of an attractive background, painter using different types of lines such as fine lines, vertical, diagonal and horizontal. Vertical lines reflect strength used in compact buildings while long and horizontal lines create form and space perspective of far and near. Repeated lines are used to show movement of 'rim' and 'handle' of the bicycle.

Repeated use of such lines give an impact of tone and effect can be seen on the uniforms, bicycles and other objects that give a realistic picture. According to Othman (2014), the use of the right lines and textures telling will obliterates the image to associate the coinciding average in Figure 2 of the drawings.

A line efficiency skill means ability to build arm movements that generate 'stroke' which actually describes the identity of the artist. Furthermore, the use of formalistic elements makes this work has its own strength. Apparently this painting using ink pen that is smooth and medium thick as the accuracy of line.These show the maturity and skills, and also prove that the artist is professional. In addition, the use of visual elements to create a dark shadow that 'fall' on the road is made with the utmost care. The element of space were emphasized to create the impression of space before the main subject, the living room is the position of the pedestrian and two vehicles, while the back room reserved for the building and the sky.

The artist use all available space to put the diversity of object and subject to make this work complete and meaningful. The principle of diversity can be implemented either through the forms of the various compositions are united in this painting. The position of main subject is placed in the middle of the paintings so that it can focus on the reader and at the same time gives the overall balance of the work. The principle of counter used in dark and bright areas such as school uniforms, can give interesting affect to the character. Moreover, the emphasis of this paper focuses on a group of students as the main character to explore the meaning and the message conveyed by the artist.

\section{Analysis for Iconography Level}

At this stage, the artwork of Mohd Yaman Ahmad Mus reveals some important background to be known in order to facilitate the interpretation done. First is the time setting, the focus of research on the vehicle registration number J792 as shown

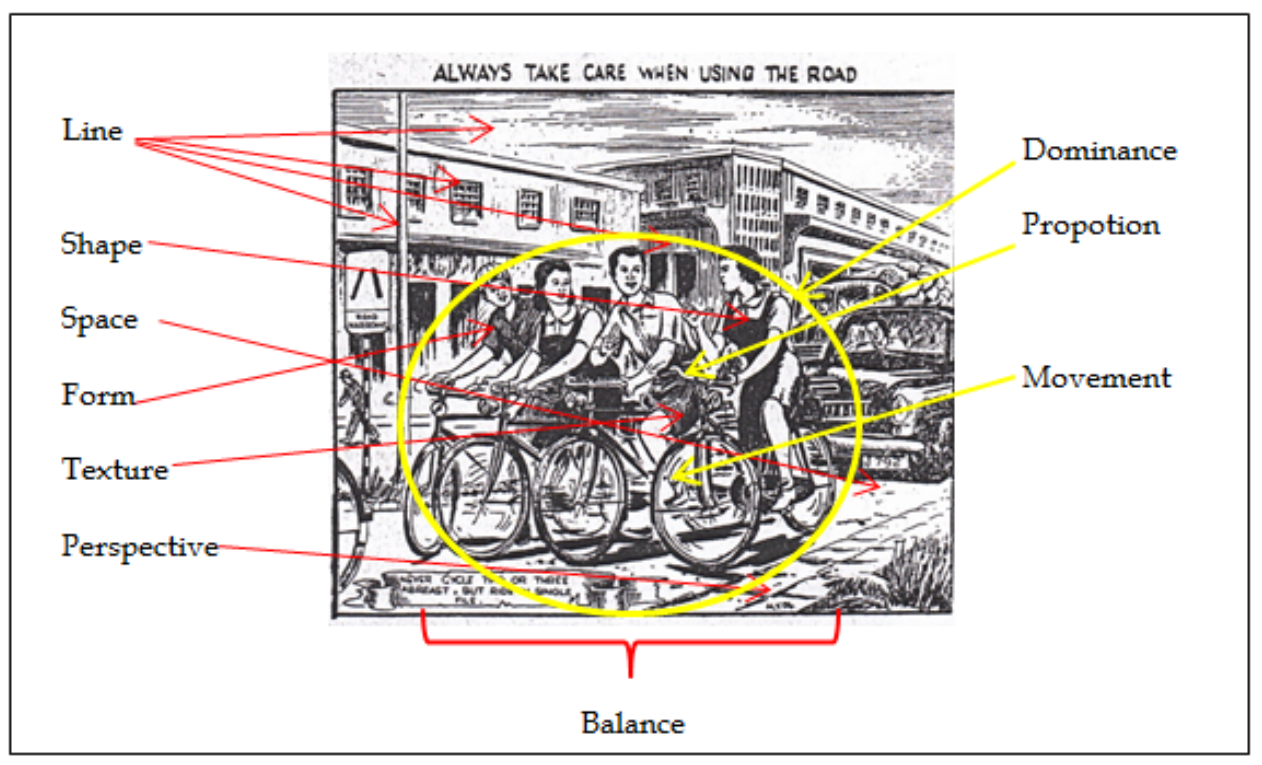

Figure 2. Application of Formal Elements in Artwork 
in Figure 3 describes the use of a registration number that was used around 1950 in Jesselton, North Borneo. For example, a car type "Wolselay" J3612 registration number registered on 18 November 1959 and "Austin 13.2cc" was registered on January 7, 1959 with registration number J2952 (Doutis Gonkit, New Sabah Times). Starting from 1968 until 1980, EJ registration numbers of motor vehicles used for the Jesselton (Sejarah Sabah dalam Gambar 1881-1981, 1981).

Car in Figure 3 (IV) is matching image of car type "Austin A40 Cambridge" that use engine capacity of $1200 \mathrm{cc}$ that were registered in 1954 and designed by Dick Burzi (www.simoncar.co.u). The discovery could match the time setting based on the image of the building as shown in Figure 3 (ii), these describes the building is a well known as Jesselton Hotel which was opened by Governor Sir Roland Turnbull in 1954 (Jesselton Dalam Kenangan 18991967, 2014:55). The hotel is located in the heart of Jalan Gaya Kota Kinabalu, Sabah until now.

While in Figure 3 (iii) also shows the type of bike used by the main characters.
The type of bicycle used around 1957 is a kind of 'Raleigh'. This type of bicycle was brought in by the British around 1890s to the nobility and British personnel who become the main vehicle and quite popular until the early ' 60 s before vehicles such as motorcycles, 'Vespa', ' lambret', and the car began to replace it (Utusan Malaysia, 20 September 2012). Raleigh bike model in 1950 is a type of "Raleigh Range Model 31 Boy , 31L Girls", "Raleigh Dawn Tourist Model 12, 12L" and type "Carrier Model 21" (www.oldroads.bostonbiker.org). In the painting, a bicycle ridden by a female character at the front is the type of "Raleigh Range Model 31L Girls" while another three characters using the model type "Raleigh Range Model 31 Boy “.

Based on the subject which is the vehicle used in the drawing above, the description of the road to be taken into account for the nature and structure of connected meanings. Road is the important element of transportation after the second world war, which was administered by British after that to rebuild roads to facilitate transportation and trade. In 1949 , the Governor made a report which is 130 miles of road

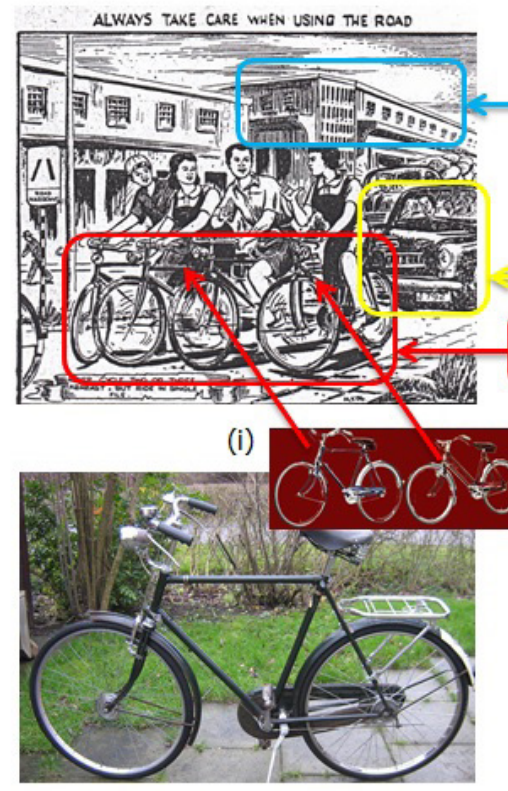

(iii)

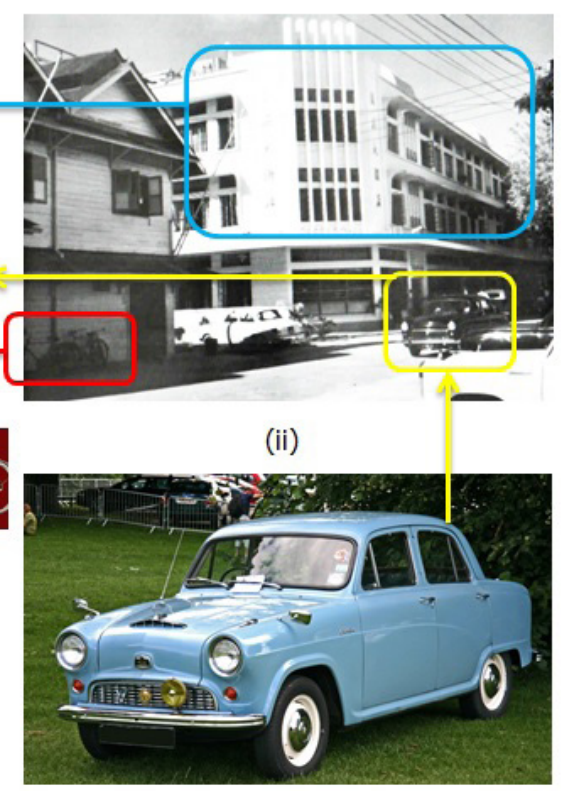

(iv)

Figure 3: Analysis of Subject and Drawing Image

[Source: Anak Sabah 1957, Jesselton Dalam Kenangan (1899-1967),

(www.simoncar.co.uk), (oldroads.bostonbiker.org.)] 
have been prepared using the "asphalt" , 23 more miles are tar, etc. 225 miles of road and 578 corresponding lane 6 feet to 8 feet wide was also prepared (Sejarah Sabah Dalam Gambar, 1881-1981 (1981:63). In the late 1950s, plans to connect the road from Kota Kinabalu to Papar which was completed in 1964, shows a rapid development of roads in Sabah. This is clearly to relate the state of the roads in Jesselton at that time when it is already at a good level in terms of smoothness and ease of public relations.

At this stage, each subject give the impression that the use of vehicles such as bicycles, cars, buildings and school uniform is suitable with the background at that time and place when the painting was produced. These evidence strengthened when the signatures artist clearly put in 1956 as a timely addition to advertising the drawing competition that advertised in the Anak Sabah newspaper which also in 1956. The use of English on the road sign and the use of symbols in the caption of this work is a symbol of colonialism that thickened in the community such as students, readers and newspapers publishers. Influence and 'stroke' artist also has similarities with western comic drawing in local newspapers such as 'Anak Sabah' and 'The Kinabalu News Bulletin' based on participant observation. Drawing style that gained control of most of the space by manipulating the pen's ink artist almost equal force artist Nora from Malaya (Peninsular Malaysia) as the drawings show every space is filled with various types of fabric with the appearance of lines and figures that are realistic and attractive landscape, his drawing style are through victorian methods (Suhaimi , 2007).

\section{Analysis of Interpretation}

The drawing is realistic to reflect the reality of the attitude of public members while on the road. Realistic approaches in the treatment bring easy understanding to the reader in order to receive messages that convey through this comic. Yet despite the message says, researchers can link a deeper meaning as a result of interpretation on the level of iconography as above. Riding bikes, talking in a "happy" and warmth atmosphere can give the connotation of a treatment that seeks to turn the mood happy and free without being aware of your surroundings. In fact, cycling is extremely effective and will become a physical fitness training that will reduce stress and can be used as an appropriate activity for all ages. However, if these activities misused or do not care about the safety factors, it can lead to injury from a fall or collision. Conversion terms 'kemalangan' to the term 'kecelakaan' which was decided by the Federal Traffic Police Chief Datuk Supian Amat said the term is more significant because it was not linked to the destiny alone but sad and tragic impacts such as the loss of life and destruction of property (The Sun, 6 April 1998).

The loss of life on the road is an event that cannot be avoided because human life cannot be taken except by a deliberate way. Even though there is no accident category featuring a person is considered to be a killer, but he still cannot escape the punishment prescribed. From the Islam point of view, perhaps he will be punished "qisas" if proven guilty (Norazmah and Jaminah , 1999 ). Islamic law was applied to cases of negligent driving that causes death. Attitude that is less concern to the narrow path actually approaching the tense atmosphere at the same time have implications for others in the vicinity. School children and adolescents represent the target group or the figure which has a big problem when on the road compared to other target groups. In other words, they do not think about safety even revealing to the danger that would be fall to themselves and others. Some adolescence at this a stage is not only giving problems in school, even at home, in public places and on the road.

Adolescence is the most challenging times in human age. No doubt at that age everything will happen as the revolt of the soul, courage and attitude blindly optimistic or too pessimistic (Lee, 2004). The 
clash between two views of the opposite corner is often the case, between the requirements and limitations. In cross- natural life, youth is not just issued of warning the others but willing to accept criticism from others. Many benefits can be obtained if we practice from the smallest little thing up to more important matters. Hence, adolescence must be willing to accept a reprimand from others for the balanced self-development and success from various points in the future. The situation that depicted busy road with other vehicles of various types shows the impact of an accident can happen to anyone regardless of place and time, as the saying goes "Unfortunate has no smell".

Negligence on the road would bring danger to life and physical injuries as well as long-lasting trauma. The bicycle image that display in the drawing appears to be no any damaged and clearly drawn in detail in terms of completeness describes the physical condition of the bicycle used must be always in good condition. The road is the most important connection tool to develop various human activities. Smooth road system function as a network of human relationships with other sectors will expedite the processing. The physical conditions such as severe road damage, holes and so on will be disrupted such dealings delayed, damaged goods and even worse pose a danger to road users. However, even the road conditions are modern and comfortable might also cause problems. The comfortable conditions and opportunities are often leading the target user to speed driving, selfish, and other offenses. Hence, even though there is a good road system and quality though, if the attitude and values of humanity are still not prioritized will still give negative implications.

Awareness about road safety was created to give guidance to road users. This awareness rooted users in human values that can ensure realization to the objective of reducing the rate of accidents on the roads reached. Awareness campaigns often remind that when riding a bicycle, stroke carefully, not speed, being careful with slippery road conditions and potholes, and be careful with the vehicle in front and in the back at a safe distance. We are urged to maintain the safety of our colleagues by avoiding talking while walking or joking like pushing on the road. Mohd Yaman Ahmad Mus work clearly emphasis on advice from other drivers who also participated as road user. This clearly showed that we should listen to the advice of other road users in the event that we made a mistake and did not comply with the rules on road. Attitude to respect older people is one of the manners that should be observed and practiced. Like the saying goes, "Respect the old men and love the young" to describe the important relationship between these two. For the pedestrian users either individually or collectively, we need to walk the sidewalks provided, always be aware of your surroundings by using the senses of sight and hearing, be careful when crossing, and make sure view to the right and to the left before crossing. We have to wait patiently until there is no longer passing vehicle. Sidewalks created to ensure the safety of people while providing smooth road system.

One of the character displays as her friends that did not participate in school uniform, which represents the youth that could influence other partners, especially the school. Thus, peer influence may be one of the causes which influenced the partnership of school, unemployed and depraved. Family factors or lack of control and oversight, troubled family because of divorce and single parents will become a contributing symptom factor of troubled teens on the road. At home, these teens can be seen through the basic family upbringing such as a lack of exposure on religious education, less applied for moral education and no affection from parents, family and relatives. Parents also need to be sensitive and aware of children when they were on the road. While the role of road users also need to keep themselves safe on the road so that parents do not give high emotions such as feeling worried and upset. Apart from that, there are other factors 
that also affect the tendency of teenagers who contributed to the crash. Research from western ever made in Malaysia by Innaci Das and Wan Rafaei in Norazmah and Jaminah (1999) on the personality of a road user crashes than those who have never experienced a traffic accident. The study found that there are specific characteristics of someone who is more prone to road accidents which is 'extrovert', 'conformity', 'neuroticism' and 'psychotic'. Table 2 below shows the relationship between these characteristics and symbols in the painting image for suitability factors that tend to cause adolescence in road accidents.
Nature 'extrovert' in Table 2 above reveals symptoms like teenagers to socialize in their group with activities that are less favorable. They are easier to take the approach of "Happy go lucky" and "outgoing" without thinking about other people, their tendency when on the road like no considerate attitude toward others. The 'conformity' is closer someone about conformity, an obedient attitude and obey a command and rules. However, this attitude is very different if the person defaults will be costly. This attitude is very important when you are on the road because it requires solidarity in the use of the highway in order

Table 2. Images Description and Interpretations

\begin{tabular}{|c|c|c|}
\hline Drawing Images & $\begin{array}{l}\text { Psychological } \\
\text { Characteristics }\end{array}$ & Linkage and Relationship \\
\hline $\begin{array}{l}\text { The attitude of } \\
\text { "Happy go Lucky" } \\
\text { and "Outgoing". }\end{array}$ & 'Extrovet' & $\begin{array}{l}\text { Teens who love to socialize, hang out } \\
\text { and socialize with friends. }\end{array}$ \\
\hline $\begin{array}{l}\text { The driver and the } \\
\text { pedestrian. }\end{array}$ & 'Conformity' & $\begin{array}{l}\text { The conformity of nature obey the } \\
\text { rules of the road do not tend to } \\
\text { crash, compared to anti -regulation, } \\
\text { rebellious and aggressive. }\end{array}$ \\
\hline $\begin{array}{l}\text { The main character } \\
\text { against the rules, } \\
\text { especially on narrow } \\
\text { roads }\end{array}$ & 'Neurotisisme' & $\begin{array}{l}\text { Modify one's behavior, anti-social, } \\
\text { less responsible and less emotionally } \\
\text { mature. }\end{array}$ \\
\hline $\begin{array}{l}\text { Active characters, } \\
\text { aggressive } \\
\text { movements. }\end{array}$ & 'Psikotik' & $\begin{array}{l}\text { Violent and aggressive and do not } \\
\text { understand other people's problems. }\end{array}$ \\
\hline $\begin{array}{l}\text { Teenagers and } \\
\text { students. }\end{array}$ & $\begin{array}{l}\text { Young age and } \\
\text { Stress Level }\end{array}$ & $\begin{array}{l}\text { Impatient, short-tempered, hasty } \\
\text { and mental disorders. }\end{array}$ \\
\hline $\begin{array}{l}\text { Male and female } \\
\text { characters. }\end{array}$ & Gender factor & $\begin{array}{l}\text { Men's more aggressive, more } \\
\text { adventurous and less patient than } \\
\text { women who quite courteous and be } \\
\text { careful on the road. }\end{array}$ \\
\hline School Uniform & Education pattern & $\begin{array}{c}\text { Learning from observation and } \\
\text { imitation, negative behavior from } \\
\text { the influence of the mass media, } \\
\text { education of family members and } \\
\text { peers. }\end{array}$ \\
\hline
\end{tabular}


to participate comply with regulations and directives have been set.

On the other hand, the "neorotisis$m e^{\prime}$ demand the responsible behavior and emotional maturity. Sensitive to the state of the roads surround through the physical and environmental impact to be more tolerant of emotion from all angles. Same are 'psychotic' which places emphasis on the main character. They appear to be active with bike riding style and looks aggressive which allow teenagers often labeled as violent. So, this attitude will be more likely to commit traffic offenses. Teenagers and students are at these age experience high levels of stress that cause an attitude impatient, short-tempered, and hasty in every action and result in mental disorders. Male characters are more likely to contribute towards road accidents than females. The attitude of men which is more aggressive, bold and impatient brings much impact on their discipline when on the road. This type of education that can be identified using a school uniform is a symbol of education, either formal or informal. Informal education occurs since childhood when at home among family members such as brothers or fathers who like to drive fast and dangerously, these will affect them. In this process, they are quick to imitate through observation and environment that tend towards negative attitude.

Such influence not only involve family members, and even the influence of the mass media also have an impact such as television, the Internet and the latest gadgets, smartphones are the result of advances in technology today. With the great influence of his friends through various aspects of negative symptoms they cause will mimic the behavior without thinking about the good and bad effects. This practice has relationship with 'social learning theory' by Albert Bandura (1969) in Norazmah and Jaminah (1999) of learning through observation and then copied the action. Adolescence is very susceptible to negative treatment because they feel fun without thinking about anything that brings a problem to them. As a result, they lack self-confidence as well as a lower mental preparation will lead to a lack of reasoning makes sense when on the road.

\section{COMICS IMAGE AND INTERPRETA- TION OF ISSUE}

Messages and lessons that can be concluded from the results of image interpretation is derived from four criteria: a) criticism and satire, b) advice and lessons, c) moral values and d) motivation. Due to the issue of road safety awareness and its attribution to human, teaching approaches and messages that will be acquired is focused on changing man attitudes. Table 2 describes the statement from teenagers and students regarding social problems that was carried away outside school. Their problems not give impact on themselves, but will inconvenience other road users. Their action is displayed through the painting clearly shows the expression on the face which is cheerful, happy, and talking is an attitude and a value that is negative. Proper cycling for recreation and physical fitness in a suitable place such as recreation centers that provide cycling tracks. Riding a bike on the road should not be together because these would pose a danger. The painter tries to convey his wishes through comic images that criticize the behavior of adolescents on common interests, improve the social level and do not affect the safety of themselves and the community (see Table 3 ).

Table 4 describes an indirect advice and guidance as a basis to see change in the attitude of road users. Consciousness is one of the psychological actions on the importance of maintaining the self-safety and others while on the road. In addition, good manners should be practice to perceived good from society and a positive impact on the actions and emotions of users. The focus on youth and school students who will become 'role models' for others to be the best example and strives to be a good role model, especially children newly increased adult. 
Table 3. Messages, criticism and satire

\begin{tabular}{|c|c|}
\hline Statement On The State Of The Road & $\begin{array}{c}\text { Relationship Of Criticism And } \\
\text { Satire }\end{array}$ \\
\hline $\begin{array}{l}\text { Social level youth and schoolchildren on the } \\
\text { roads. }\end{array}$ & Social problem. \\
\hline Self-harm and inconvenience to others. & and others \\
\hline talked not located. & Self \\
\hline The attitud & Selfish \\
\hline $\begin{array}{l}\text { Truckers carrying more illegal road, threatening } \\
\text { and damaging way. }\end{array}$ & The threat of lif \\
\hline
\end{tabular}

Table 4. Messages and Lessons

\begin{tabular}{ll}
\hline Changes In Attitude On The Road & Keywords \\
\hline $\begin{array}{l}\text { Alerting the public how important it is to keep yourself and others } \\
\text { safe on the road }\end{array}$ & Awareness \\
$\begin{array}{l}\text { Maintaining good manners and polite when on the road } \\
\text { School children and adolescents should be examples for other } \\
\text { groups. }\end{array}$ & $\begin{array}{l}\text { Polite manners } \\
\text { Model and } \\
\text { example }\end{array}$ \\
$\begin{array}{l}\text { Recognize and realize themselves and others about the conse- } \\
\text { quences of an accident }\end{array}$ & Realize \\
$\begin{array}{l}\text { Attempting to take heed to the punishment of the offender laws } \\
\text { road. }\end{array}$ & Punishment \\
\hline
\end{tabular}

Table 5. Positive Attitude and Positive Issue Values

\begin{tabular}{|c|c|}
\hline Good Manners On The Road & Relationship With Moral Values \\
\hline Obey with road laws & Responsible \\
\hline Not speed driving & Considerate, honest and rational. \\
\hline Not talking and joking on the road. & Concern and trust. \\
\hline Does not rushing & Pateint and rational \\
\hline $\begin{array}{l}\text { Be careful and be aware of your sur- } \\
\text { roundings }\end{array}$ & Responsibility and trust. \\
\hline $\begin{array}{l}\text { Ensuring a safe distance with the vehicle } \\
\text { in front and back. }\end{array}$ & Virtuous, tolerant and independent. \\
\hline Protect each other. & Thoughtful, rational and affection. \\
\hline $\begin{array}{l}\text { Riding for individuals who are not in } \\
\text { tandem. }\end{array}$ & Responsible, working and caring . \\
\hline $\begin{array}{l}\text { Sensitive situation around, always see } \\
\text { and hear the traffic situation. }\end{array}$ & Caring, tolerant and self-esteem. \\
\hline $\begin{array}{l}\text { Advise other road users with utmost } \\
\text { prudence }\end{array}$ & $\begin{array}{l}\text { Responsibility, honesty, caring, honest } \\
\text { and loving. }\end{array}$ \\
\hline $\begin{array}{l}\text { There is a strain that can harass other } \\
\text { users. }\end{array}$ & $\begin{array}{l}\text { Thoughtfulness, patience, tolerance } \\
\text { and moderation. }\end{array}$ \\
\hline Not overloading that can pose a danger. & Responsibility, trust and caring. \\
\hline $\begin{array}{l}\text { By using the sidewalks, we can avoid ac- } \\
\text { cidents and drivers who are not courte- } \\
\text { ous. }\end{array}$ & Responsibility, trust and fairness. \\
\hline
\end{tabular}


Table 6. Messages and Relation to Motivation

\begin{tabular}{|c|c|c|}
\hline Action & Effect & $\begin{array}{l}\text { Motivation } \\
\text { competency }\end{array}$ \\
\hline $\begin{array}{l}\text { Law enforcement by the Road } \\
\text { Transport Department to increase } \\
\text { enforcement operations increased } \\
\text { due to accident statistics. }\end{array}$ & $\begin{array}{l}\text { Public users can comply } \\
\text { with rules of the road. }\end{array}$ & $\begin{array}{c}\text { Motivation As the } \\
\text { driver }\end{array}$ \\
\hline $\begin{array}{c}\text { Road safety education in schools } \\
\text { because of social factors of students } \\
\text { outside school contribute to road } \\
\text { accidents }\end{array}$ & $\begin{array}{l}\text { Knowledge, awareness } \\
\text { and the importance of } \\
\text { maintaining the safety of } \\
\text { self and others . Setting } \\
\text { up a road safety club. }\end{array}$ & $\begin{array}{l}\text { As the degree of } \\
\text { seriousness of mo- } \\
\text { tivation }\end{array}$ \\
\hline $\begin{array}{l}\text { The presence of police officers } \\
\text { psychologically scary instructs the } \\
\text { driver so as not to break the rules . }\end{array}$ & $\begin{array}{l}\text { Consumers remain vigi- } \\
\text { lant so as not to follow } \\
\text { the rule }\end{array}$ & $\begin{array}{l}\text { Motivation As } \\
\text { Stimulator }\end{array}$ \\
\hline $\begin{array}{l}\text { Education community- dare to } \\
\text { show themselves to provide infor- } \\
\text { mation, to combat bullying and } \\
\text { gangsterism on the roads. Love } \\
\text { and religious education of parents. }\end{array}$ & $\begin{array}{l}\text { Responsible society } \\
\text { would reduce this prob- } \\
\text { lem. }\end{array}$ & $\begin{array}{l}\text { Motivation As } \\
\text { Catalyst Courage }\end{array}$ \\
\hline Penalties and fines. & $\begin{array}{l}\text { Offenders will seek to } \\
\text { recognize and repair } \\
\text { mistakes in the future. }\end{array}$ & $\begin{array}{l}\text { As the degree of } \\
\text { seriousness of mo- } \\
\text { tivation }\end{array}$ \\
\hline
\end{tabular}

The messages that conveyed through this illustration is all about awareness of personal safety while on the road with regard to moral values that become the 'benchmark' important to change human behavior on the road. Related values of responsibility, trust, rational and tolerant attitude to dominate the match against road users is as if there is no value at all, making that the level of awareness and concrete action to reduce the rate of road accidents will be unsuccessful. It is, therefore, good values will develop character and personal growth balanced against emotionally, intellectually, physically and spiritually. Table 5 describes the attitude of a good pitching that will be connected with the appropriate moral values. Values are responsible for the highest level of awareness of human primary responsibility themselves, others and the environment.

This includes compliance with the regulations and laws of road, always careful, understand the situation itself and sur- rounding. Become considerate is also important to put yourself always safeguard to the interests of self and others such as not speeding, follow the instructions, advise others and do not give rise to tensions which can harass other users.

Based on the destination of many artists produce drawing that was interpreted criticism, advice and exposure to moral values that give a significant boost to the elements, catalysts, flame burner or the like to give a negative or positive effect towards the efforts and achievements are referred to as motivation. To obtain the effect of motivation, there are many parties that will be associated not only subjects in this painting are affected. Table 6 describes some of the parties involved to relate the motivation could be obtained by the author. Law enforcement by the Jabatan Pengangkutan Jalan (Road Transport Department) is to increase enforcement operations due to the increased accident statistics. These factors motivate to strive even harder to give ma- 
ximum effect to the user to better comply with the rules of the road. Social factors of students outside the school contribute to road accidents motivate the seriousness of road safety education in schools, which also involved parties such Majlis Keselamatan Jalan Raya (Road Safety Council), Jabatan Pengangkutan Jalan (Road Transport Department) Polis DiRaja Malaysia (Royal Malaysian Police) and researchers such as psychologists. Motivation level of seriousness of this degree will be able to affect the knowledge society and have a high level of awareness.

Motivation as the degree of seriousness can also be seen through the execution of sentences and fines to the offender laws road. These steps can motivate the offender to repent and will try to repair the errors in the future. The presence of police officers in the field of road psychologically can give lessons to scare drivers not to violate the rules. The motivation for this simulator can educate consumers indirectly to always be careful and follow the laws that have been established. Motivation of the community itself is also important to be seen to be responsible as possible to reduce the problem of indifference to other users. For example, someone dared to appear as witnesses to provide information on the outcome, the fight against bullying and gangsterism on the roads. This cooperation should take place not only see this responsibility lies with the authorities only. The people who help are people who care and take appropriate redress and justice. Parents and family members should also play an important role in charge of educating children, because young people like this youth is the number of road users. Motivation should be given to them in a way to create awareness of personal safety. The motivation level inspired the love between family members than to cut ties and increased the level of high emotional intelligence.

\section{CONCLUSION}

As a conclusion, all walks of life in
Sabah and Malaysia in particular, should take heed and realize the importance of awareness for the safety of themselves, others and the collective. Attitude and behavior while on the road is very concerned with the moral values of good, able to advise fellow society, criticism and have a high level of motivation. These criteria are useful as self- defense and is the main weapon in combating youth social problems and so be able to apply good manners and has a tendency toward greater awareness and public safety on the road.

Message by community awareness stewardship comics Mohd Yaman Ahmad Mus significant back then because he produced such works as are at the age of 16 years. He is well-known as a talented painter since his school days until adulthood often makes social themes in the piece. He is a painter who wisely uses personal experience to expose the social problems of young people and society to be brought to the reader is to give a message and a lesson useful to all. Comic Mohd Yaman Ahmad Mus in the press media to convey clear messages and social criticism even in the form of a comic image. His paintings seek to meet the slogan "Art for the People" that can bring benefits to the global community of harmony and happiness.

\section{REFERENCES}

Ahmad, H. (2010). Keluarga dan Masyarakat. Dewan Masyarakat. Dewan Bahasa dan Pustaka.

Anak Sabah. (1957, January). Result of Girl Guide Drawing Competition, 4.

Arkib. (2008, August 18). Jesselton Dalam Kenangan (1899-1967).

Arnold, Hauser. (1982). Sosiology of Art. Routledge \& Kegan Paul.

Bee, A. (1993). Konflik di antara Kaum Remaja Dengan Ibu Bapa. Seminar Ke Arah Pembangunan Keluarga Bahagia. Terengganu.

Enstice, Wayne and Peters. (2003). Melody, Drawing: Space, Form and Expression. New Jersey. Pearson Prentice Hall.

Feldman, E.B. (1981). Varieties of Visual 
Experience. New York: Harry N. Kementerian Kebudayaan Belia dan SuAbrams, Inc.

Ferni, E. (1995). Art History and Its Methods : Critical Anthology, London : Phaidon.

Gonkit, D. (2011). New Sabah Times. Kota Kinabalu.

Ibrahim, N.\& dan Ibrahim, J. (1999). Nahas Jalan Raya: Punca, Implikasi dan Penyelesaiannya. Koleksi Kertas Kerja Psikologi Masyarakat Malaysia Semasa, Sekolah Psikologi dan Kerja Sosial. Universiti Malaysia Sabah. Kota Kinabalu.

Ismail. I. (2005). Sejarah Perkembangan Seni Lukis Sabah. Kota Kinabalu: Universiti Malaysia Sabah.

Ibrahim, I. (2011). Datuk Mohd. Yaman Ahmad Mus. Kota Kinabalu: Universiti Malaysia Sabah.

Lee, T.L. (2004). Fokus E-masteri SPM Pendidikan Moral. Bangi: Penerbitan Pelangi.

McQuail, Dennis. (1994). Mass Communication Theory: An Introduction (3rd ed). London: Sage Publication.

Mohd Johari Ab. Hamid. (2006). Asas Seni Visual. Tanjong Malim: Universiti Pendidikan Sultan Idris.

Mahamood, M. (1995). Seni Lukis Dalam Peristiwa. Kuala Lumpur: Dewan Bahasa dan Pustaka.

Mahamood, M. (1999). Pengantar Seni Lukis Kartun. Kuala Lumpur: Univision Press.

Othmanm, M.N. (2014). Isu dan Pemikiran Dalam Seni Visual. Kuala Lumpur: Dewan Bahasa dan Pustaka. kan. (1981). Pameran 100 Tahun Lukisan, Fotografi dan Kebudayaan Sempena Expo Sabah 1881-1981. Kota Kinabalu.

Padasia, J. (1981). Sejarah Sabah Dalam Gambar 1881-1981. Kota Kinabalu: Jawatankuasa Penerbitan.

Panofsky, E. (1955). Meaning In Art. Chicago: University of Chicago Press.

Pradopo, R.D. (1994). Prinsip-prinsip Kritik Sastra. UGM Press : hlm. 10.

Rahman, A. bin Aziz. (1997). Motivasi dan Pembangunan Diri. Utusan Publication \& Distributors Sdn. Bhd.

Suhaimi, A. M. N. (2007). Sejarah Kesedaran Visual di Malaya. Tanjong Malim: Universiti Pendidikan Sultan Idris.

Sunarto, P. Metafora Visual Kartun Editorial pada Surat Kabar Jakarta 19501957. Dissertation. Bandung: Institut Teknologi Bandung.

Read, H. (1951). The Meaning of Art. Great Britain: Faber and Faber.

Ragans, R. (1995). Art Talk. $2^{\text {nd }}$ ed. Ohio: Macmillan/McGraw-Hill.

Rosiah Md Noor dan Azian Tahir. (2009). Analisis Kandungan Karya Seni Halus Menerusi Pendekatan Model 'Organic Unity' in Isu-isu Seni Kontemporari. Kota Kinabalu. Universiti Malaysia Sabah, p. 293-302.

Shahir, S. (2011). Lukisan: Beberapa Catatan Idea Persepsi dan Proses dalam $1^{\text {st }} \mathrm{Ma}-$ laysian International Drawing Marathon, Pusat Pengajian Seni, Universiti Sains Malaysia Pulau Pinang. 